\title{
Management of the production potential of a construction company
}

\author{
Marina Barbarskaya ${ }^{1, *}$, Alla Larkina $^{1}$, and Elena Trubchaninova ${ }^{1}$ \\ ${ }^{1}$ Samara State Technical University, 443100, 244 Molodogvardeyskaya str., Samara, Russia
}

\begin{abstract}
The paper is devoted to the management of the production potential of a construction company. The importance of the production potential as one of the most significant elements of the organization resource base is substantiated in the article. Theoretical foundations of the concept of "production potential" and the element structure of the production potential are considered. The management of the production potential is considered from the point of view of the system approach. Taking into account the specifics of the construction sector, the structure of the managing subsystems, such as the target, supporting, managed and managing ones, is represented. The implementation of management decisions in the system of management of the productive potential is to ensure an increase in the management effectiveness of all elements of the production potential, contribute to its further development, and enhance efficiency of a construction company as a whole.
\end{abstract}

\section{Introduction}

To implement economic activities, achieve the planned goals and solve the assigned tasks, the company must have necessary resources at its disposal. The key to the successful operation of the organization is the availability of the necessary amount of resources, taking into account their rational use. Characterizing the resources that are at the company's disposal, such concepts as "resource base" and "resource potential" are very often used. At present, there is no single approach to the definition of these concepts, and, in general, scientists understand under these terms the totality of all the resources that economic entities possess. The resource base characterizes the production capabilities of the organization, taking into account the specific nature of the economic activity of the economic entity, the stage of the life cycle, and the assessment of the influence of external and internal factors. The organization's resources are an essential element of its internal environment and they include the capital at its disposal, human resources, materials and reserves, and technology and information resources. Formation of the resource base of an economic entity is a complex, multi-step process that encompasses planning, organization and control.

Construction as an economic activity has a number of specific characteristics, which include the duration of the production cycle, high material consumption and the cost of production, and complexity of work performed. Moreover, the construction activity is a kind of activity, in which new assets are created that all sectors of the economy need. Therefore, the dynamics of volumes of production in all other sectors, the economy as a whole, and the

\footnotetext{
*Corresponding author: mnb_82@inbox.ru
} 
change in social development indicators depend on how well the entities engaged in the investment-building process are provided with resources. In this connection, the relevance of the topic of the paper and the issues it questions are obvious.

\section{Theoretical basis for studying the essence of the concept of "productive potential"}

The production potential is the main element of the resource potential of the organization. The objective assessment of the production capacity of a construction company, the use of rational approaches in the process of resource management, such as the timely updating of fixed assets, the use of modern materials and technologies in construction, the involvement of highly skilled workers, will enable it to significantly improve production efficiency. As a result, the end product of its activities will have the characteristics that correspond to all quality standards in construction, the proper degree of reliability in the process of operation, that is, will fully meet all the requirements and expectations of consumers of the construction products. In turn, this will indicate the competitiveness of the company on the occupied market segment, the reliability of the organization for all participants of the investment and construction process, including for potential customers and the third parties.

The effectiveness of the activities of any organization, including those engaged in such economic activities as construction, is determined by the impact of a variety of factors, the key of which is its resources. An objective assessment of the level of production potential allows the construction company formulating a strategy for its activities and determining the directions of tactical decisions. Disclosure of the concept of "productive potential", the process of assessment and management of the productive potential is considered in the publications of many foreign and domestic scientists.

The works of S. Muravsky (1989), Campbell R. McConnell and Stanley L. Bru (1992), D.B. Epshtein (1990), V. Svobodin (1993), L.B. Vinnechek (2011), Francisco J. Forteza (2015), Jose M. Carretero-Gómez (2015), Albert Sesé (2015), etc. [1-6] are devoted to the analysis of the concept of "productive potential". Summarizing these works, it should be noted that the production potential at the macro level is defined as "the regional volume of output that is possible to produce with the full use of available resources" [2]. The productive potential is a complex socio-economic category, including the resource potential, the production process and the final product, which also implies a level of socio-economic effectiveness $[1,3]$. The productive potential is characterized by the composition and state of the company's fixed and circulating assets, as well as its human resources. In a number of cases, the production potential of an organization is associated with the production capacities. In this case, the definition will be as follows: "The production potential is an opportunity to produce a certain volume of output at a certain time" [4].

In general, the analysis of scientific publications allows us noting two approaches to the disclosure of the concept of "productive potential". In the framework of the first approach, the production capacity is considered from the point of view of the resources available to the organization. The element structure of the production potential of a construction company is presented on the Figure 1. Also, this approach assumes an assessment of the effectiveness of their use. 


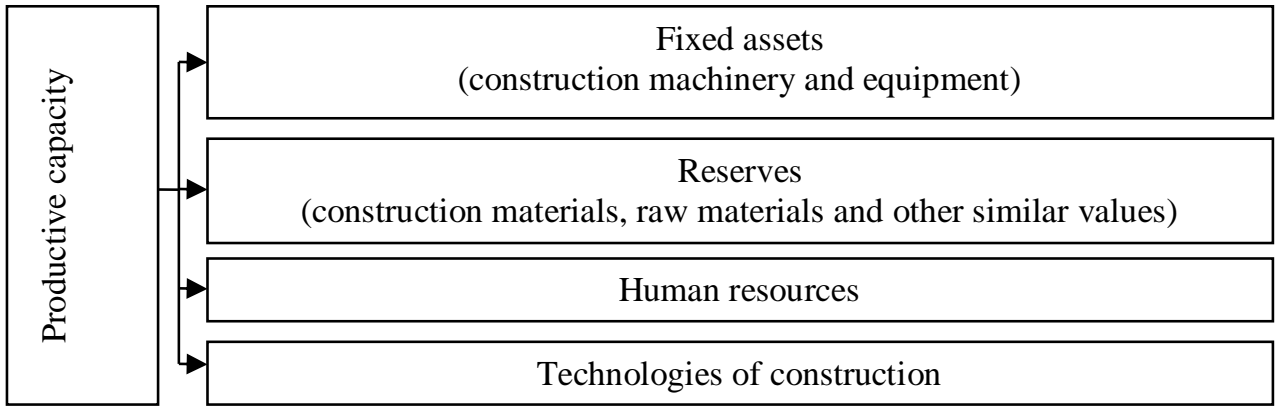

Fig. 1. Elements of the production capacity of a construction company.

The viewpoint of the second approach is based on the fact that the production potential of an organization is the ability of the organization to use all its available resources, taking into account the maximum degree of efficiency of their use. The approaches discussed above complement each other, especially when considering issues related to the assessment of the productive potential of the organization. Since it was already mentioned above that the construction activity has a number of features, it is reasonable to use the first approach when assessing the current cost of its resources.

\section{Assessment of the production capacity of a construction company}

The indicators of the assessment of the company's productive potential are detailed in the publications of L.V. Davydov (2010), A.V. Chumakova (2010), V.B. Melekhina (2014), M.A. Saidova (2014), France Gagnon (2018), Tim Aubry (2018), J. Bradley Cousins (2018), Swee C. Goh (2018), Catherine Elliott (2018) and other scientists [7-9]. In their works, the authors focus on the fact that the objective assessment is one of the key problems in the process of managing the productive potential of a company and is necessary for the organization of its effective activity. Performing an assessment of the organization's production capacity, it is necessary to take into account the specific features of the elements that form it. Moreover, the assessment of the overall capacity of the organization should be one of the components of the company management system and an element of the organizational development.

When assessing the production capacity of a construction company, taking into account the strategy of its activities and the formation of competitive advantages, it is necessary to turn to the second approach. The system of indicators for assessing the production capacity of the construction company, taking into account the generalization of the approaches discussed above, is presented on the Figure 2. 


\begin{tabular}{|c|c|}
\hline \multicolumn{2}{|c|}{$\begin{array}{l}\text { Assessment of the production capacity of a construction } \\
\text { company }\end{array}$} \\
\hline & \\
\hline $\begin{array}{l}\text { Indicators of evaluation in terms of } \\
\text { available resources }\end{array}$ & $\begin{array}{l}\text { Indicators of evaluation in terms of } \\
\text { efficient use of resources }\end{array}$ \\
\hline$\downarrow$ & 7 \\
\hline $\begin{array}{l}\text { - Cost of fixed assets; } \\
\text { - The specific weight of the active part } \\
\text { of fixed assets in their total value; } \\
\text { - Coefficient of renewal of fixed assets; } \\
\text { - Factor of retirement of fixed assets; } \\
\text { - Factor of depreciation of fixed assets; } \\
\text { - Factor of the validity of fixed assets; } \\
\text { - Fund capacity; } \\
\text { - Coefficient of real value of property of } \\
\text { production purpose; } \\
\text { - Cost of inventory; } \\
\text { - Measurement ratio of material } \\
\text { resources; } \\
\text { - Norms of expenditure of material } \\
\text { resources; } \\
\text { - The coefficient of rhythm of supply; } \\
\text { - The coefficient of variation; } \\
\text { - Coefficient of uneven delivery; } \\
\text { - Number of employees; } \\
\text { - Professional and qualification } \\
\text { composition of workers. }\end{array}$ & $\begin{array}{l}\text { - Capital return on fixed assets; } \\
\text { - Return on assets of the active part of } \\
\text { fixed assets; } \\
\text { - Capital intensity of fixed assets; } \\
\text { - Profitability of fixed assets } \\
\text { - Material intensity of the construction } \\
\text { works; } \\
\text { - Return on the construction works; } \\
\text { - Profitability of material costs; } \\
\text { - Gross profit per ruble of material costs; } \\
\text { - Profitability of construction activities; } \\
\text { - Absolute and relative release of working } \\
\text { capital; } \\
\text { - Production of all employees; } \\
\text { - Production of workers; } \\
\text { - Labor productivity growth rate; } \\
\text { - The share of growth in construction } \\
\text { work performed by increasing } \\
\text { productivity; } \\
\text { - Absolute and relative release of } \\
\text { employees; } \\
\text { - The utilization rate of the useful fund of } \\
\text { working time; } \\
\text { - Labor intensity of the construction work }\end{array}$ \\
\hline
\end{tabular}

Fig. 2. The system of indicators for assessing the production potential of a construction company

The indicators considered on the Figure 2 are fundamental in the process of managing the production potential of a construction company. The elaboration of management decisions aimed at further developing the production potential simultaneously involves an assessment of the organization's productive potential in terms of the resources at its disposal, and an assessment of the effectiveness of their use in the previous period.

\section{Formation of the management system of the production potential of a construction company}

The management of the production potential of companies, including construction ones, should be viewed from the position of a systematic approach. These issues are addressed in the works of such foreign scientists as P. Drucker (2004), Richard L. Daft (2006), Michael H. Mescon (1997), etc., and domestic researchers R.A. Fatkhutdinova (1997), B.Z. Milner, L.I. Evenko, V.S. Rapoprot (1988), A.V. Yavkina (2010), S.V. Kabanova (2007), etc. [1016]. It is known that with a system approach, any system is viewed as a set of interrelated elements that are oriented toward achieving the set goals, taking into account external and 
internal factors of development [15]. The implementation of the system approach to managing the production capacity of a construction company should be based on the following methodological principles:

- Setting goals and objectives for managing the production capacity;

- Principles and methods of managing the production potential;

- Functions of managing the production potential;

- Information resources necessary for managing the production potential;

- The process of development and implementation of management decisions aimed at improving the efficiency of use and development of the productive capacity.

The formation of a system of managing the production potential of a construction company, taking into account the interaction of these methodological aspects, allows us justifying the development and implementation of management decisions aimed at improving the management of productive capacity, taking into account the strategy and objectives of the organization. The management system of the production potential of the construction company is presented on the Figure 3.

The system of production potential management is consists of subsystems. The target subsystem is the underlying one. In this case, the purpose of the management system is to increase the efficiency of using the productive capacity of the construction company and its further development. Taking into account the strategic intentions of the construction company, the results of the assessment of the impact of external and internal factors, based on the methodological foundations of the system approach, the specifics of implementation of the supporting, managed and managing subsystems are determined. The main function that is entrusted to the supporting subsystem of management is to form the composition and volume of the resource base of the company, taking into account the types of construction works and the planned volumes of construction production. At this stage, it is also very important to focus on the technological component of the process of construction production, including knowledge and skills of workforce to work with these or other technologies of construction. The implementation of the supporting system is not possible without the "functioning" of the managed system. In its framework, the production potential is assessed from the point of view of the resources available to the construction organization (Figure 2). Here, the innovative component of the organization activities is also considered. But, taking into account the specifics of the construction industry, it should be noted that construction is a kind of economic activity in which, due to a number of objective reasons, it is rather difficult to apply innovative technologies. So, for example, innovative technologies are not fully in demand among developers, as developers themselves, as well as consumers of the construction products do not have full confidence in them. More preference is given to both "proven" construction materials and technologies. 


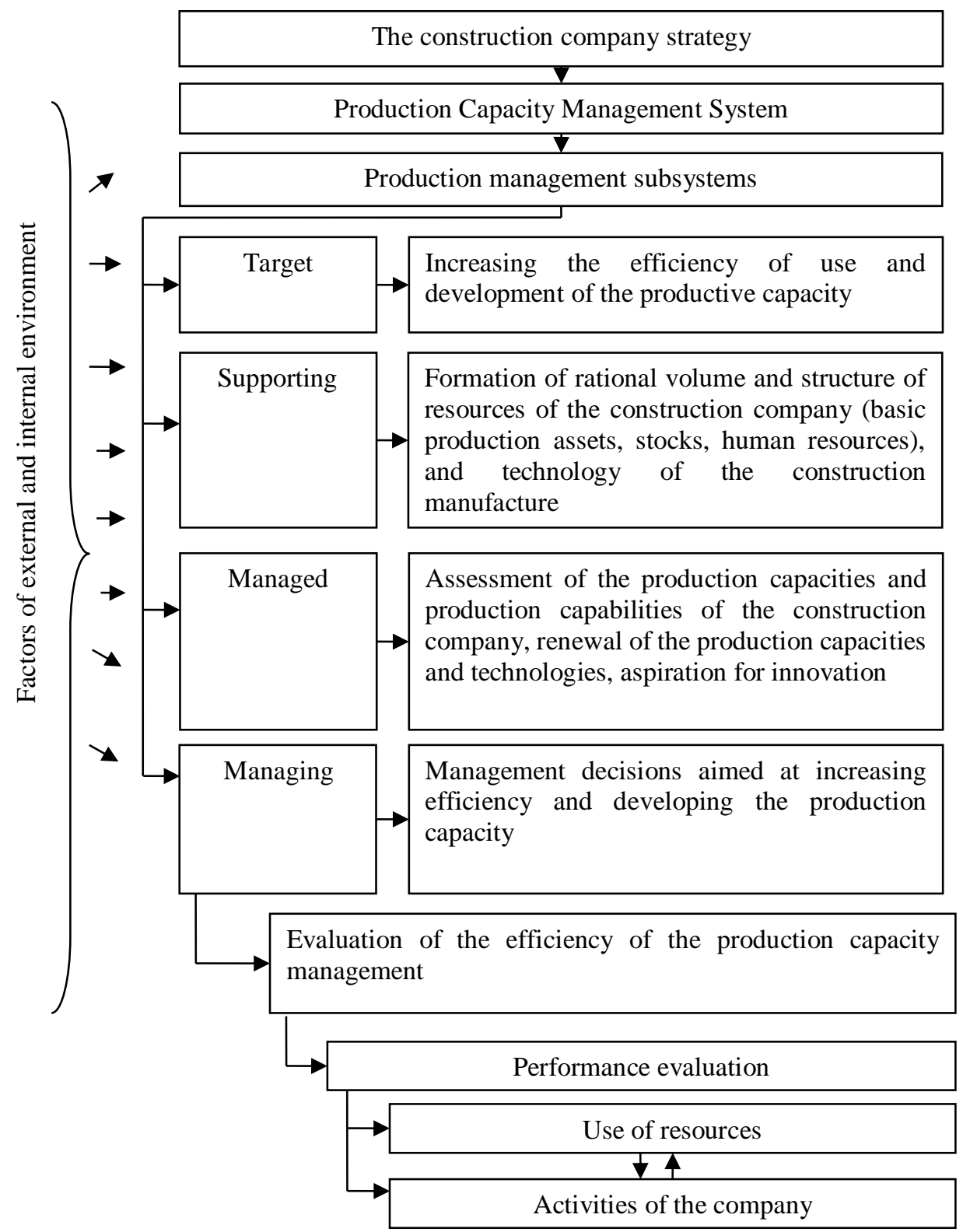

Fig. 3. The management system of the production potential of a construction company.

The management subsystem is focused on the elaboration of management decisions aimed at increasing the efficiency of use and further development of the production capacity of the construction organization. Directions of management decisions, taking into account the results obtained at the implementation stages of the supporting and managed subsystems, should cover all the structural components of the production capacity of the construction company (Figure 1). Taking into account the specifics of the construction industry, one should pay attention, first of all, to the state of the basic production assets, the quality of construction materials, and the level of knowledge and skills of managers and workers employed on the construction sites. Management decisions aimed at optimizing the composition of fixed assets will help their timely updating, reducing downtime in 
construction, reducing the costs of maintenance and repair of production equipment, and increasing return on assets and reducing capital intensity. In order to improve the efficiency of inventory management, the type of a policy for managing current assets is determined, and the objectivity of methods for planning and normalizing reserves is assessed. Programs aimed at increasing social security of workers, improving skills, retraining and mentoring, etc. can be targeted to improve the effectiveness of the use of human resources.

\section{Conclusions}

The set of management subsystems presented on the Figure 3, aimed at improving the efficiency of management and developing the productive potential, ultimately implies an increase in the efficiency of activities of the construction company as a whole. If each of the management subsystems has fully fulfilled its functional load, then at the stage of assessing the effectiveness of the implemented management decisions, positive dynamics of indicators of profitability of activities and efficiency of the use of resources (fixed productive assets, reserves, and human resources) should be obtained. That is, as a result of improving management efficiency and developing production capacity, the construction company receives more revenue and profit through optimization of the construction costs and more rational use of the resource base. Together, this indicates the growth of business activity of the construction company, the strengthening of its competitive status and the reliability of activities for all participants of the investment and construction process.

\section{References}

1. S. Muravsky, Agribusiness: Economics and Management, 3, 53-56 (1989)

2. K. R. McConnell, S. L. Bru, Economics: principles, industry and politics (Republic, Moscow, 1992)

3. L. Vinnechek, Regional Economy: Theory and Practice, 7, 190, 42-46 (2011)

4. D. Epstein, Economics, 12, 103-125 (1990)

5. V. Svobodin, Agribusiness: Economics and Management, 3, 27-42 (1993)

6. F. J. Forteza, J. M. Carretero-Gómez, Albert Sesé, Journal of Safety Research, 62, 185198 (2017)

7. L. V. Davydova, A. V. Chumakova, Scientific Bulletins - Series in History, Political Science, Economy, Computer science, 13, 84, 67-71 (2010)

8. V. B. Melekhin, M. A. Saidov, Naukovedeniye, 4, 23 (2014)

9. F. Gagnon, T. Aubr, J. B. Cousins, S. C. Goh, C. Elliott, Evaluation and Program Planning, 68, 166-175 (2018)

10. P. F. Drucker, The tasks of management in the 21st century (Williams, 2004)

11. R. L. Daft, Management (Moscow, 2006)

12. M. Meskon, M. Albert, F. Hedouri, Foundations of management (Delo, Moscow, 1997)

13. R. Fatkhutdinov, Management system (Intel-Sintez, Moscow, 1997)

14. B. Milner, L. Evenko, V. Rapoport, System approach to organization in management (Ekonomika, Moscow, 1988)

15. A. Yavkin, Transport Business in Russia, 12, 34-37 (2010)

16. S. Kabanov, Izvestiya IGEA, 5, 55, 90-91 (2007) 